\title{
Colchicine Intolerance: Does the Pharmaceutical Preparation Matter?
}

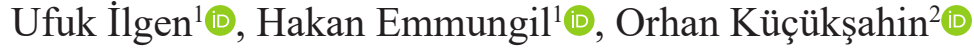 \\ 'Department of Rheumatology, Trakya University School of Medicine, Edirne, Turkey \\ ${ }^{2}$ Department of Rheumatology, Ankara Yıldırım Beyazıt University School of Medicine, Ankara, Turkey
}

\section{To the Editor,}

Recently, 3 observational studies, one in adult ${ }^{1}$ and 2 in the pediatric population, ${ }^{2,3}$ were published regarding the efficacy of different pharmaceutical colchicine preparations in familial Mediterranean fever (FMF). It was consistently shown that patients resistant to sugar-coated tablets might benefit from compressed colchicine tablets, and this was explainable by different pharmacokinetic properties of the preparations. ${ }^{1}$ Moreover, resistant and intolerant patients to sugar-coated tablets may benefit from the compressed ones, as shown by Türkuçar et al. in their study in the pediatric population published in the January 2021 issue of the Balkan Medical Journal. ${ }^{3}$ Intolerance to colchicine, mostly due to diarrhea, is a major barrier to increase the dose to a level adequate to control the attack frequency. We want to share our experience of compressed colchicine tablets in adult FMF patients intolerant to sugar-coated tablets.

Fourteen patients, older than 18 years of age, followed up in 3 centers in Turkey (Liv Hospital, Ankara, Yıldırım Beyazıt University Atatürk Training and Research Hospital, Ankara \& Trakya University Hospital, Edirne) from 2015 to 2020, with a clinical diagnosis of FMF meeting Tel Hashomer criteria ${ }^{4}$ and under treatment with Colchicine opocalcium ${ }^{\circledR}$ (Mayoly Spindler, France), a compressed colchicine preparation, due to intolerance to sugar-coated tablets (Colchicum-Dispert ${ }^{\circledR}$, Recordati, Turkey \& Kolsin ${ }^{\circledR}$, İbrahim Etem Ulagay, Turkey), were identified and included in the study. Patients under anti-interleukin 1 or other biological agents were excluded.

Eight $(57.1 \%)$ were females, and the median age and disease duration was 32 (range: $21-44$ ) and 8 (range: $2.5-18$ ) years, respectively. Attack characteristics and $M E$ diterranean $F$ eVer $(M E F V)$ gene mutation profile were provided in Figure 1. All patients had diarrhea, defined as 3 or more loose/liquid stools per day, with sub-optimal doses of sugar-coated colchicine tablets, and none had diarrhea under the compressed tablets. The frequency of the attacks significantly decreased after the pharmaceutical change (Figure $1 \mathrm{a}-\mathrm{c}$ ), although the daily colchicine doses were similar $(1.5 \pm 0.25$ and $1.56 \pm 0.52 \mathrm{mg} /$ day before and after the pharmaceutical change, respectively). Median duration under the sugar-coated and compressed tablets was 5 (range: $0.5-10$ ) and 2.5 (range: 1-8) years.

As a major limitation, this study was not a head-to-head comparison of different pharmaceutical preparations of colchicine and did not involve patients intolerant to the compressed colchicine tablets. The patient group was also small. But it was evident that some FMF patients intolerant to the sugar-coated tablets may benefit from the compressed colchicine tablets. In this subgroup of patients, the treatment seems sustainable.

Ethics Committee Approval: Ethics committee approval was received for this study from the Institutional Review Board of Trakya University School of Medicine (TÜTF BAEK 2019/150-06/44).

Patient Consent for Publication: Written informed consent was obtained from each patient regarding the use of clinical data for research purposes.

Author Contributions: Concept - U.İ., H.E., O.K.; Design - U.İ., H.E., O.K.; Supervision - H.E., O.K.; Materials - U.İ., H.E., O.K.; Data Collection and/or Processing - U.İ., H.E., O.K.; Analysis and/or Interpretation - U.İ., H.E., O.K.; Literature Review - U.İ., H.E., O.K.; Writing - U.İ., H.E., O.K.; Critical Review - U.İ., H.E., O.K.

Conflict of Interest: The authors declare no conflict of interest.

Funding: The authors declared that this study had received no financial support.

\section{REFERENCES}

1. Emmungil H, İlgen U, Turan S, Yaman S, Küçükşahin O. Different pharmaceutical preparations of colchicine for familial Mediterranean fever: are they the same? Rheumatol Int. 2020;40(1):129-135. [CrossRef]

2. Baglan E, Ozdel S, Bulbul M. Do all colchicine preparations have the same effectiveness in patients with familial Mediterranean fever? Mod Rheumatol. 2021;31(2):481484. [CrossRef]

3. Türkuçar S, Otar Yener G, Adıgüzel Dundar H, et al. Comparison of different pharmaceutical preparations of colchicine in children with familial Mediterranean fever: is colchicine Opocalcium a good alternative? Balk Med J. 2021;38(1):29-33. [CrossRef]

4. Pras M. Familial Mediterranean fever: from the clinical syndrome to the cloning of the pyrin gene. Scand J Rheumatol. 1998;27(2):92-97. [CrossRef]

Address for Correspondence: Ufuk İlgen, Department of Rheumatology, Trakya University School of Medicine, Edirne, Turkey

e-mail: ufukilgen@gmail.com

Received: February 19, 2021 Accepted: April 9, 2021 • DOI: 10.5152/balkanmedj.2021.21128

Available at www.balkanmedicaljournal.org

ORCID iDs of the authors: U.İ. 0000-0001-6443-6426; H.E. 0000-0001-5184-4404; O.K. 0000-0003-4530-2304.

Cite this article as:

İlgen U, Emmungil H, Küçükşahin O. Colchicine intolerance: Does the pharmaceutical preparation matter?. [published online ahead of print, 2021 June 4]. Balkan Med J. 2021;38(4):257-258.

Copyright@Author(s) - Available online at http://balkanmedicaljournal.org/ 
(a)

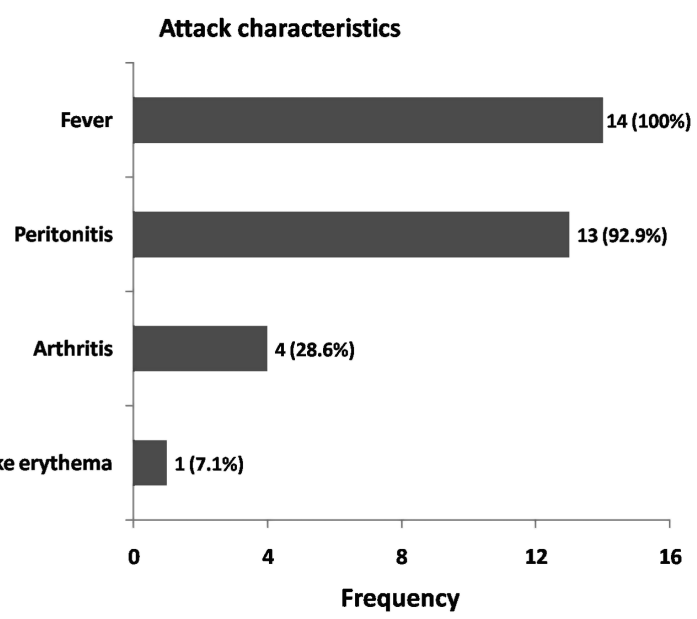

(b)

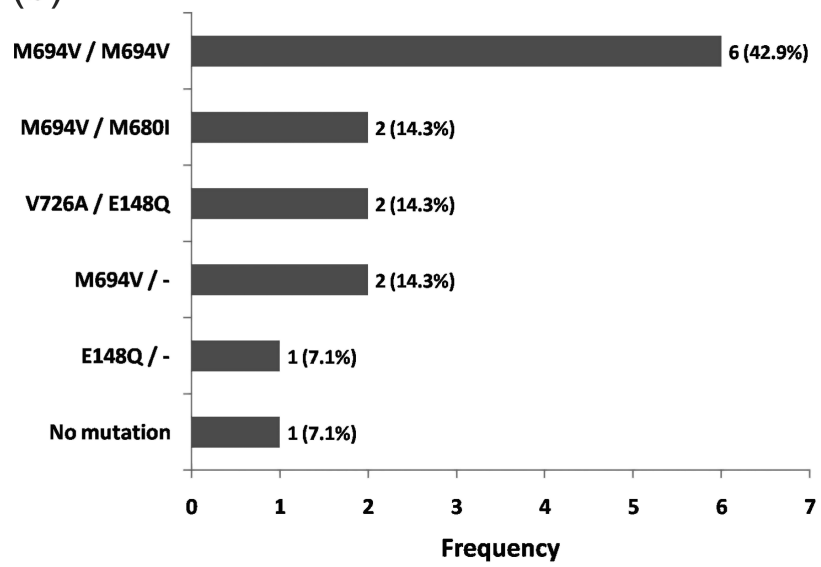

(C) Number of attacks in the last six months before and after the pharmaceutical change

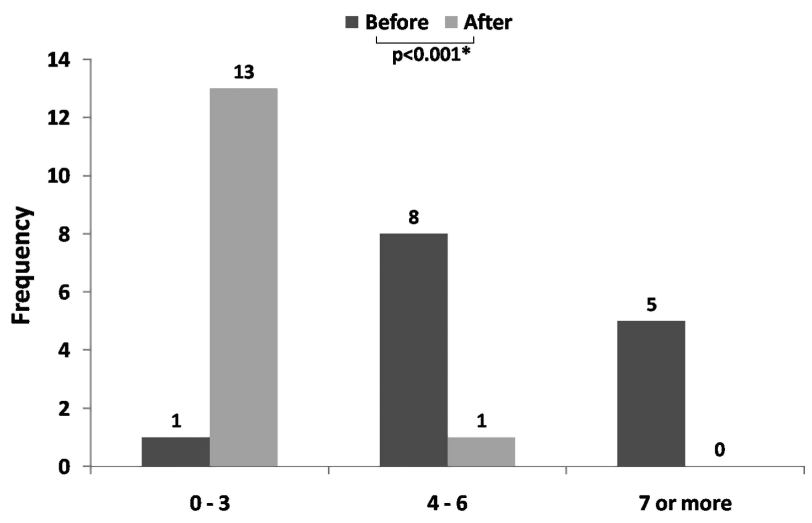

FIG. 1. Clinical features. (a-c). Attack characteristics (a) and MEditerranean FeVer (MEFV) gene mutation profile (b) of the patients. Note that the number of attacks decreased significantly after the pharmaceutical change (c). "Wilcoxon signed-rank test. 